\title{
The effect of levosimendan in a patients with postinfarction ventricular septal de- fect
}

\section{İnfarktüs sonrası ventriküler septal defektli hastada Levosimendan'ın etkisi}

\author{
*Hasan Yücel ${ }^{1}$, Ali Zorlu ${ }^{1}$, Hakkı Kaya ${ }^{1}$, İbrahim Gül ${ }^{1}$ \\ ${ }^{1}$ Department of Cardiology, Cumhuriyet University School of Medicine \\ Corresponding author: Dr. Hasan Yücel, Kardiyoloji Anabilim Dalı, Cumhuriyet Üniversitesi Tip \\ Fakültesi , TR-58140, Sivas \\ E-mail: drhasanyucel@hotmail.com \\ Received/Accepted: November 04, 2014/March 13, 2015 \\ Conflict of interest: There is not a conflict of interest.
}

\section{SUMMARY}

This paper reports the clinic course of a patient with postinfarction ventricular septal defect (VSD). At the period to surgery, the patient received levosimendan for cardio-protection. During the levosimendan infusion, the hemodynamics of the patient worsened. The impairment of hemodynamics and mortality of the patient might be responded to the increase of the amount of left to right shunt, which had possibly occurred due to levosimendan treatment.

Keywords: Levosimendan, acute myocardial infarction, ventricular septal defect, shunt

ÖZET

$\mathrm{Bu}$ yazı, akut miyokard infarktüsü sonrası ventriküler septal defekt (VSD) gelişen birhastanın klinik seyrini içermektedir. Cerrahiyi bekleme sürecinde, hastaya kardiyak koruma amacıyla levosimendan infüzyonu başlandı. İnfüzyon esnasında hastanın hemodinamisi kötülești. Hemodinamideki bozulmanın, levosimendan tedavisine sekonder soldan sağa şant miktarının artışına bağlı olabileceği düşünüldü.

Anahtar sözcükler: Levosimendan, akut miyokard infarktüsü, ventriküler septal defekt, șant

\section{INTRODUCTION}

Ventricular septal defect (VSD) is a rare but a fatal complication of acute myocardial infarction (MI) ${ }^{1}$.

Current guidelines for the treatment of postinfarction VSD recommend immediate surgical repair, regardless of clinical status $^{2}$. In the period to surgery, it may be longer with some reasons, intra-aortic balloon pumping (IABP) provides temporary but effective early medical stabilization. Positive inotropic agents are used generally to patients with hypotension $(<90$ or 80 $\mathrm{mmHg}$ ) or cardiogenic shock, but there is no data about the benefits or risks of this treatment ${ }^{3,4}$. There is growing data about perioperative use of levosimendan for cardioprotection in the patients who under- went cardiac surgery ${ }^{5}$. The effects of levosimendan on acute heart failure (HF) complicated by postinfarction VSD are discussed here through a case in which levosimendan was used for cardioprotection before cardiac surgery.

\section{CASE REPORT}

This paper reports the clinic course of a patient with postinfarction VSD. He was 65 years old and hospitalized for subacute anterior MI. There was ST segment elevation and negative $\mathrm{T}$ waves on electrocardiography. Troponin levels at admission was high (Troponin I: $28 \mathrm{ng} / \mathrm{mL}$ ). Echocardiography revealed an aneurysm at anteroseptal region of left ventricle (LV) and ejection fraction (EF) was approximately 35 percent. The patient was hemodynamically 
stable at the first day. On the second day, the patient complained of chest pain and dyspnea. A new holosystolic harsh murmur was auscultated, and VSD was found on bed-side echocardiography.

Immediately performed coronary angiography and left ventriculography confirmed the postinfarction VSD, and showed total occlusion on proximal left anterior descending artery (LAD) and severe stenosis on right coronary artery (RCA). Immediate surgery for VSD and coronary bypass was planned. However, the patient could not be immediately operated because of ongoing discussions with surgeons. In the same day, blood pressure was $110 / 70 \mathrm{mmHg}$, but urine excretion (UE) felt below $30 \mathrm{cc} / \mathrm{h}$, and the serum creatinine levels $(\mathrm{Cr})$ raised over $2 \mathrm{mg} / \mathrm{dL}$ along with increase in blood urea nitrogen levels (BUN) over $60 \mathrm{mg} / \mathrm{dL}$. Following IABP and nitroprusside infusion, UE increased over $50 \mathrm{cc} / \mathrm{h}$ and $\mathrm{Cr}$ felt below 2 $\mathrm{mg} / \mathrm{dL}$, BUN remained at similar levels. The patient was managed via this therapeutic plan for three days. At fifth day, intravenous levosimendan infusion was started and after 24 hours infusion of levosimendan, the surgery was performed.

The patient suffered nonsustained ventricular tachycardia episodes, $\mathrm{Cr}$ levels raised over $2.5 \mathrm{mg} / \mathrm{dL}$, BUN over $90 \mathrm{mg} / \mathrm{dL}$, and UE felt below $40 \mathrm{cc} / \mathrm{h}$ during levosimendan infusion. On the operation, a saphenous vein graft between aorta and RCA was placed and left internal mammarian artery was anastomosed to LAD. The VSD was repaired via left ventriculotomy by internal patch. After these processes, the patient could not be weaned from extracorporeal perfusion pump (ECPP) and succumbed to death.

\section{DISCUSSION}

Postinfarction VSD complicated $1 \%$ to $2 \%$ of acute MI before the reperfusion era ${ }^{1,6}$. The patient reported here did not receive thrombolytic therapy because of late admission, and had large infarct area, so an aneurysm at LV. It has been showed that levosimendan improves the outcomes of patients undergoing cardiac surgery, especially with cardiotomy and ECPP and become much more frequently used for this aim $^{5}$.
Despite no invasive hemodynamic measurements were performed in the patient reported here, the UE and serum ureacreatinine levels, which are important markers for cardiac output, were deteriorated after the infusion of levosimendan and ventricular arrhythmias appeared. It might be also due to contrast induced nephropathy (CIN) or to enlargement of the VSD or decompensation of HF. However, hemodynamic improvement was observed after IABP, suggesting the impairment was not responded to CIN. On the other hand, development of arrhythmias may suggest further impairment of cardiac function and not renal impairment. If the reason of hemodynamic impairment was decompensation of HF, levosimendan would be expected beneficial at that situation. The clinical findings suggest that levosimendan might be the reason of impairment of hemodynamics, through increasing the amount of left to right shunt, as discussed below.

The favorable effects of levosimendan are known in acute $\mathrm{HF}^{7}$. There are no data about the effects of levosimendan on hemodynamic parameters in patients with postinfarction or other forms of VSD. Conflicted data were reported for other positive inotropic agents when used in other forms of $\mathrm{VSD}^{8,9}$. Positive inotropic agents were used in postinfarction VSD, when cardiogenic shock occurs. There are no adequate data about whether they are beneficial or harmful. Levosimendan has theoretically beneficial effects in the situation of postinfarction VSD, in which right ventricular failure (RVF) eventually occurs. It was shown that levosimendan may improve right ventricular functions and clinical signs in patients with $\mathrm{RVF}^{10}$. On the other hand, the amount of left to right shunt was found higher in patients with higher EF than those with lower EF in patients with postinfarction VSD ${ }^{4,11}$. This finding suggests that increasing contractility with a positive inotropic agent, e.g. levosimendan, may increase the amount of left to right shunt and compromise functions of right ventricle further and may decrease the cardiac output, as observed in this patient. The amount of left to right shunt before and after levosimendan therapy could be measured by echocardiog- 
raphy in this patient, although the retrospective analysis of the patient has became it impossible. The preoperative LVEF was not associated with in hospital or 30-day mortality in patients undergoing surgical or percutaneous repair ${ }^{4}$. Although in other report, the patients who survived operative repair had larger shunts on average than the nonsurvivors ${ }^{11}$. According to this acknowledgement, the impairment of hemodynamics and mortality of the patient might be responded to the increase of the amount of left to right shunt, which had possibly occurred due to levosimendan treatment.

In patients with postinfarction VSD, cardiogenic shock or acute HF could be said to be secondary to mechanical problems, and, as in those with postinfarction VSD, inotropic therapy without apparent afterload reduction might bring about increased contractility and increased left to right shunt, which may result in RVF earlier. Finally, the use of levosimendan or other positive inotropic agents in patients with postinfarction VSD with the aim of perioperative cardioprotection or treatment of $\mathrm{AHF}$ is a matter requiring more attention.

\section{REFERENCES}

1. Pohjola-Sintonen $\mathrm{S}$, Muller JE, Stone PH. Ventricular septal and free wall rupture complicating acute myocardial infarction: Experience in the Multicenter Investigation of Limitation of Infarct Size. Am Heart J 1989; 117: 809-18.

2. Van de Werf F, Bax J, Betriu A. Management of acute myocardial infarction in patients presenting with persistent ST-segment elevation: The Task Force on the Management of ST-Segment Elevation Acute Myocardial Infarction of the European Society of Cardiology. Eur Heart J 2008; 29: 2909-45.

3. Menon V, Webb JG, Hillis LD. Outcome and profile of ventricular septal rupture with cardiogenic shock after myocardial infarction: A report from the SHOCK Trial Registry. SHould we emergently revascularize Occluded Coronaries in cardiogenic shocK? J Am Coll Cardiol 2000; 36: 1110-6.
4. Maltais S, Ibrahim R, Basmadjian AJ. Postinfarction ventricular septal defects: Towards a new treatment algorithm? Ann Thorac Surg 2009; 87: 687-92.

5. Landoni G, Mizzi A, BiondiZoccai G. Reducing mortality in cardiac surgery with levosimendan: A meta-analysis of randomized controlled trials. J Cardiothorac Vasc Anesth 2010; 24: 517.

6. Moore CA, Nygaard TW, Kaiser DL. Postinfarction ventricular septal rupture: the importance of location of infarction and right ventricular function in determining survival. Circulation 1986; 74: 4555.

7. Mebazaa A, Nieminen MS, Packer M. Levosimendan vs dobutamine for patients with acute decompensated heart failure: The SURVIVE Randomized Trial. JAMA 2007; 297: 1883-91.

8. Boucek MM, Chang R, Synhorst DP. Hemodynamic consequences of inotropic support with digoxin or amrinone in lambs with ventricular septal defect. Pediatr Res 1985; 19: 887-91.

9. Momoi N, Sato M, Sato K. Hemodynamic effects III inhibitor in patients with a large ventricular leftto-right shunt. Jpn Circ J 2000; 64: 249-53.

10. Yilmaz MB, Yontar C, Erdem A. Comparative effects of levosimendan and dobutamine on right ventricular function in patients with biventricular heart failure. Heart Vessels 2009; 24: 16-21.

11. Lowe JE, Gall SA Jr. As originally published in 1989: Correlates of survival with postinfarction ventricular septal defect. Ann Thorac Surg 1997; 63: 1508-9. 